\title{
Głos w dyskusji: „Czy można odstąpić od usunięcia pachowych węzłów chłonnych przy dodatniej biopsji węzła wartowniczego w raku piersi?"
}

W ostatnim ubiegłorocznym zeszycie Nowotworów opublikowano "głosy w dyskusji" nt. usuwania pachowych węzłów chłonnych przy dodatnim wyniku biopsji węzła wartowniczego w raku piersi, prowadzonej podczas I Konferencji Naukowej pisma [1, 2]. W Klinice Nowotworów Piersi i Chirurgii Rekonstrukcyjnej Centrum Onkologii w Warszawie minęło już 10 lat od wprowadzenia do rutynowego stosowania biopsji węzła wartowniczego, dlatego postanowiłem dołączyć swój głos do toczącej się dyskusji.

Stan węzłów chłonnych u chorych z rozpoznanym rakiem piersi jest od wielu dekad uznanym czynnikiem prognostycznym. Obiektywna ocena węzłów chłonnych wiąże się z koniecznością ich usunięcia i oceną histopatologiczną, ale - jak wiadomo, szczególnie przy prowadzonych programach skriningowych raka piersi odsetek chorych operowanych z powodu raka piersi, u których stwierdzono przerzuty do węzłów pachy, wynosi obecnie mniej niż 20\%. Wiadomo również, że usuwanie węzłów chłonnych niezawierających przerzutów jest niecelowe i niesie za sobą pogorszenie jakości życia oraz zwiększenie kosztów leczenia i rehabilitacji tych chorych. Dlatego od około 20 lat rozpoczęto wdrażanie procedury biopsji węzła wartowniczego jako alternatywę do elektywnej limfadenektomii.

W obecnym piśmiennictwie medycznym ucichły już dyskusje nad zasadnością, techniką i wskazaniami do biopsji węzłów wartowniczych w przypadkach pierwotnie operacyjnego raka piersi, dominujące w początkowym okresie wprowadzania tej metody do praktyki klinicznej. Metoda ta zyskała już powszechną akceptację, a ośrodki specjalizujące się w kompleksowym leczeniu raka piersi stosują ją rutynowo. Nowym problemem, który wymaga rozwiązania przy powszechnym stosowaniu tej metody, jest zasadność wykonywania limfadenektomii pachowej w każdym wypadku stwierdzanego przerzutu do węzła/węzłów wartowniczych. Rozwój technik patologicznych i ocena kliniczna pozwoliły na zdefiniowanie trzech grup przerzutów raka piersi do węzła wartowniczego: izolowanych komórek nowotworowych, mikroprzerzutów oraz makroprzerzutów. W ocenie większości klinicystów obecność izolowanych komórek no- wotworowych i mikoprzerzutów w węźle wartowniczym nie ma istotnego wpływu na przebieg choroby i praktycznie w takiej sytuacji odstępuje się od wykonywania limfadenektomii. Stwierdzane makroprzerzuty były klasycznym wskazaniem do radykalnego usunięcia węzłów chłonnych regionalnego spływu. Dyskusja pomiędzy prof. A. Jeziorskim i prof. J. Jaśkiewiczem jest kontynuacją polemik środowiska onkologów, które pojawiły się po publikacji wyników badania ACOSOG Z0011.

W trakcie biopsji węzłów chłonnych wartowniczych pobieranych jest do badania średnio 1,2-3,4 węzłów chłonnych $[3,4]$. U około 70\% chorych stwierdzone w węźle wartowniczym przerzuty są jedynymi przerzutami stwierdzonymi w ocenianym spływie chłonnym [5]. Prawdopodobnie dlatego nie stwierdzono zwiększonej liczby wznów miejscowych w spływie chłonnym u chorych poddanych jedynie biopsji węzłów wartowniczych. Zalecenia o odstąpieniu od limfadenektomii w oparciu o wyniki badania ACOSOG Z0011 określają na 1-2 maksymalną liczbę wartowniczych węzłów chłonnych zmienionych przerzutowo.

W przedstawionych w Nowotwory Journal of Oncology artykułach [1, 2] nie przeprowadzono analizy częstości wznów miejscowo-regionalnych u chorych na raka piersi, u których stwierdzono nietypowy (poza dołem pachowym) spływ chłonny. Istnieją przypadki dwukierunkowego spływu chłonnego: do dołu pachowego i okolicy przymostkowej, w takiej sytuacji przerzuty do węzłów pachowych zwiększają prawdopodobieństwo przerzutów do węzłów przymostkowych $[6,7]$. Takie sytuacje kliniczne wymagają indywidualnych decyzji terapeutycznych, a poszerzenie zabiegu o limfadenektomię pachową bez weryfikacji węzłów chłonnych przymostkowych wydaje się klinicznie nieuzasadnione.

Dzisiaj w ocenie histopatologicznej raków piersi posługujemy się powszechnie określeniem podtypów biologicznych raka. Implikuje to rodzaj leczenia adiuwantowego. Młody wiek chorych, u których nie stosowano radioterapii i u których odstąpiono od limfadenektomii pachowej, może być czynnikiem zwiększającym ryzyko wznowy w przy- 
padku "dodatniego" węzła wartowniczego [8]. Wydaje się, że podtyp biologiczny raka piersi i planowane leczenie uzupełniające powinny mieć wpływ na decyzje o zakresie postępowania chirurgicznego w przypadku stwierdzenia makroprzerzutów do węzłów wartowniczych. Powinno się zdefiniować grupę chorych, u których „bezpiecznie” można odstąpić od limfadenektomii.

Przedstawione przeze mnie problemy ze wskazaniami do limfadenektomii w przypadku przerzutów do węzłów wartowniczych u chorych z rakiem piersi wydają się komplikować udzielenie prostej odpowiedzi na tytułowe pytanie. Ale czyż wyjaśnieniu tego nie służą prospektywne badania kliniczne?

\section{Dr med. Jacek Piechocki}

Klinika Nowotworów Piersi i Chirurgii Rekonstrukcyjnej

Centrum Onkologii — Instytut im. Marii Skłodowskiej-Curie

$w$ Warszawie

e-mail:piechoja@wp.pl

\section{Piśmiennictwo}

1. Jeziorski A. Czy można odstąpić od limfadenektomii pachowej przy przerzutach do węzła chłonnego wartowniczego? Nowotwory J Oncol 2013; 63: 493-496.

2. Jaśkiewicz J. Czy można odstapić od usunięcia pachowych węzłów chłonnych przy dodatniej biopsji węzła wartowniczego w raku piersi? Stanowisko "przeciw". Nowotwory J Oncol 2013; 63: 497-500.

3. Donker M, Straver ME, van Tienhofen G i wsp. Comparison of the sentinel node procedure between patents with multifocal and unifocal brest cancer in the EORTC 10981-22023 AMAROS Trial: identification rate and nodal outcome. Eur J Cancer 2013; 49: 2093-2100.

4. Ban EJ, Lee JS, Koo JS i wsp. How many sentinel lymph nodes are enough for accurate axillary staging in T1-2 breast cancer? J Breast Cancer 2011: $14 ; 296-300$.

5. Albertini JJ, Lyman $\mathrm{GH}$, Cox C i wsp. Lymphatic mapping and sentine node biopsy in patient with breast cancer. JAMA 1996; 276: 1818-1822.

6. Qiu PF, Zhao RR, Liu YB i wsp. Internal mammary sentinel node biopsy should still performed, especially in the patient with clinically positive axillary lymph nodes. The Breast 2013; 22: 999-1000.

7. Gnerlich JL, Barreto-Andrade JC, Czechura T i wsp. Accurate staging with internal mammary chain sentinel node biopsy for breast cancer. Ann Surg Oncol 2014; 21: 368-374.

8. van Wely BJ, van den Wildenberg FJ, Gobardhan P i wsp. Axillary recurrences after sentinel lymph node biopsy: a multicentre analysis and follow - up of sentinel lymph node negative breast cancer patients. Eur J Surg Oncol 2012; 38: 925-931.

W dniu 27 września 2014 r. odbędzie się w Warszawie Konferencja „Radioterapia śródoperacyjna - doświadczenia ośrodków polskich”

pod patronatem:

Dyrektora Centrum Onkologii — Instytutu im. Marii Skłodowskiej-Curie Polskiego Towarzystwa Onkologicznego, Oddziału Warszawskiego Polskiego Towarzystwa Chirurgii Onkologicznej

Organizatorzy:

Zakład Brachyterapii

Klinika Nowotworów Piersi i Chirurgii Rekonstrukcyjnej

Zakład Fizyki Medycznej

Centrum Onkologii — Instytutu im. Marii Skłodowskiej-Curie w Warszawie

Miejsce:

Budynek Profilaktyki Nowotworów CO-I ul. Roentgena 5, Warszawa

Zgłoszenia:

brachyterapia@coi.waw.pl

\section{W dniu 4 października 2014 r. odbędzie się w Warszawie \\ Konferencja Naukowo-Szkoleniowa \\ "Czerniak i inne nowotwory skóry — postępy w diagnostyce i leczeniu"}

Organizatorzy:

Polskie Towarzystwo Chirurgii Onkologicznej

Akademia Czerniaka — Sekcja PTChO działająca pod patronatem Polskiego Towarzystwa Onkologii Klinicznej

i Polskiego Towarzystwa Dermatologicznego

Centrum Onkologii — Instytut im. Marii Skłodowskiej-Curie w Warszawie

Przewodniczący Komitetu Naukowego i Organizacyjnego: prof. dr hab. med. Piotr Rutkowski

Miejsce obrad:

Radisson Blu Sobieski Warsaw

Plac Zawiszy 1, 02-025 Warszawa

Informacje i zgłoszenia: http://www.dermatoonkologia2014.skolamed.pl/ 